\title{
Reviewer List
}

$\begin{array}{ll}\text { Marisa Abrajano } & \text { Susanne Beechey } \\ \text { Martha A. Ackelsberg } & \text { Caroline C. Beer } \\ \text { Melinda Adams } & \text { Christina E. Bejarano } \\ \text { Petra Ahrens } & \text { Todd L. Belt } \\ \text { Julie Ajinkya } & \text { Sara Bentivegna } \\ \text { Nikol G. Alexander-Floyd } & \text { Adam J. Berinsky } \\ \text { Jilda M. Aliotta } & \text { Benjamin Bishin } \\ \text { Michael E. Allison } & \text { Amy E. Black } \\ \text { Kristi Andersen } & \text { Charles H. Blake } \\ \text { Leah Seppanen Anderson } & \text { Marella Bodur } \\ \text { Merrindahl Andrew } & \text { Catherine Bolzendahl } \\ \text { Michele Penner Angrist } & \text { MaryAnne Borrelli } \\ \text { Sarah Anzia } & \text { Angela L. Bos } \\ \text { Kevin Arceneaux } & \text { Vanessa Bouche } \\ \text { Jane Arscott } & \text { Donna Lee Bowen } \\ \text { Lonna Rae Atkeson } & \text { Lauren L. Bowen } \\ \text { Carol Atkinson } & \text { Janet M. Box-Steffensmeier } \\ \text { David Backer } & \text { Marla Brettschneider } \\ \text { Karen L. Baird } & \text { Craig Leonard Brians } \\ \text { Lisa Baldez } & \text { Hannah E. Britton } \\ \text { Maryann Barakso } & \text { Charles D. Brockett } \\ \text { Barbara B. Bardes } & \text { Michelle D. Brophy-Baermann } \\ \text { Tiffany D. Barnes } & \text { Mitchell Brown } \\ \text { Charles J. Barrilleaux } & \text { Susan R. Burgess } \\ \text { Elliot M. Bartky } & \text { Jennie Burnet } \\ \text { Sylvia B. Bashevkin } & \text { Barbara C. Burrell } \\ \text { Amrita Basu } & \text { Paul Burstein } \\ \text { Martin Battle } & \text { Dan Butler } \\ \text { Gretchen M. Bauer } & \text { Anne Byrne } \\ \text { Michael Baum } & \text { Rhonda L. Callaway } \\ \text { Sherrie L. Baver } & \text { Ernesto F. Calvo } \\ \text { Emily Ann Beaulieu } & \text { Frances Camilleri-Cassar } \\ \text { Karen Beckwith } & \text { Anne Marie Cammisa } \\ & \end{array}$


Rosie Campbell

Donatella Campus

Teri L. Caraway

John M. Carey

Royce A. Carroll

Susan J. Carroll

Terrell Carver

Erin C. Cassese

Jocelyne Cesari

Stefanie Chambers

Larry W. Chappell

Sarah Childs

Seung-Whan Choi

David L. Cingranelli

Hilde Roza Coffe

Cheryl N. Collier

Eileen Connolly

Daniel John Conway

Elizabeth Adell Cook

Linda J. Cook

Rosalyn Cooperman

Irasema Coronado

Anne N. Costain

Kimberly B. Cowell-Meyers

Robert H. Cox

Renee A. Cramer

Adriana Maria Crocker

Melody Crowder-Meyer

Drude Dahlerup

Louise K. Davidson-Schmich

Matthew K. Davis

Christine L. Day

Melissa Deckman

Jane S. DeHart

Janna L. Deitz

Debra L. DeLaet

Iva Ellen Deutchman

Lorraine Bayard de Volo

Jeff R. DeWitt

Shirin S Deylami
Scott Alan Dittloff

Steven J. Doherty

Kathleen Dolan

Casey Byrne Dominguez

Jay K. Dow

Conor M Dowling

Joshua Kjerulf Dubrow

Brian Duff

Paige Whaley Eager

Lynn M. Eckert

Richard Eichenberg

Laurel Elder

Robert S. Erikson

Justin Esarey

Maria C. Escobar-Lemmon

Diana Evans

Katalin Fabian

David M. Farrell

Michaele L. Ferguson

Myra Marx Ferree

Joel S. Fetzer

Jennifer Fitzgerald

Hawley Fogg-Davis

John P. Forren

Linda L. Fowler

Richard L. Fox

Brian Frederick

Lenita Freidenvall

Kim L. Fridkin

Sally Friedman

Scott A. Frisch

Sarah Fulton

James C. Garand

J. David Gillespie

Marianne Githens

Elizabeth Goodyear-Grant

Sharon Gramby-Sobukwe

Steven Greene

Eugenia K. Guilmartin

Dorothy Guyot 
Philip Habel

Carol Hagemann-White

Donald Haider-Markel

Ivy Orr Hamerly

Martin Ejnar Hansen

Allison Harell

Shireen Hassim

Danny Hayes

Kerry L. Haynie

Heather Heckel

Alena Heitlinger

Vicki L. Hesli

Eric H. Hines

Magda Hinojosa

Season Hoard

Anne Maria Holli

Mirya R. Holman

Ole R. Holsti

Christina Holtz-Bacha

Homa Hoodfar

Marc Hooghe

Denise M. Horn

Vicki Hsueh

Melanie M Hughes

Suraj Jacob

Farida Jalalzai

Carolyn C. James

Barbara Jancar-Webster

Jane S. Jaquette

Patricia A. Jaramillo

Douglas Edward Jarvis

Ted G. Jelen

M. Kent Jennings

Martin Johnson

Julia S. Jordan-Zachery

Amy Kaler

Alice Kang

Kristin L. Kanthak

Johanna Kantola

David Karol
Jeffrey A. Karp

Sean Q. Kelly

Kate M. Kenski

Barbara Sgouraki Kinsey

Anna R. Kirkland

Jason F. Kirksey

Miki Caul Kittilson

Jytte Klausen

Casey A. Klofstad

Jeffrey W. Koch

Hagar Kotef

Thad Kousser

Andrea Krizsan

Mona Lena Krook

Martha E. Kropf

Sheri Kunovich

Jonathan McDonald Ladd

Laura I. Langbein

Joy Langston

Christopher W. Larimer

Christopher N. Lawrence

J. Celeste Lay

David L. Leal

Debra J. Liebowitz

Mary-Kate Lizotte

Emanuela Lombardo

Sherry R. Lowrance

David I. Lublin

Jennifer C. Lucas

Jane Mansbridge

Mack Mariani

Lori Marso

Lanethea Mathews

Mary K. Meyer McAleese

Ian McAllister

Monika L McDermott

Gail McElroy

Eric McGhee

Susan Jane McWilliams

Melissa K. Miller 
Kristen Renwick Monroe

Celeste M. Montoya

Jana Morgan

Annalyssa Gypsy Murphy

Rainbow Murray

Kimberly L. Nalder

Sharon Ann Navarro

Meghana Nayak

Jody Neathery-Castro

Carol Nechemias

Megan Neely

Jacquetta Newman

David Niven

Hans Noel

Barbara Norrander

Noelle Helen Norton

Jeffrey B. Nugent

Maureen Rand Oakley

Diana Z. O’Brien

Karen O'Connor

Jennifer Olmsted

Heather L Ondercin

Valerie R. O'Regan

Shannon Kathryn Orr

Tracy Osborn

Marian Lief Palley

Manju Parikh

Amy S. Patterson

Pamela Paxton

Kathryn Pearson

Birgit Pfau-Effinger

Jennifer M. Piscopo

Eric Plutzer

Sarah Poggione

Jeremy Clayne Pope

Elizabeth M. Prügl

Nicholas Pyeatt

Vicky Randall

Ronald B. Rapoport

Beth Reingold
Laurie A. Rhodebeck

Helen Mary Rizzo

Joseph W. Roberts

Jean C. Robinson

Rene R. Rocha

Karen Ross

Mark J. Rozell

Marilyn Rueschemeyer

Sara Lacy Rushing

Kira Sanbonmatsu

Tammy A. Sarver

Birgit Sauer

Kyle L. Saunders

Marian Sawer

Martin A. Schain

Nancy Scherer

Wendy J. Schiller

Hans Peter Schmitz

Monica C. Schneider

Ronnee Schreiber

Leslie A. Schwindt-Bayer

John M. Sides

Laura Sjoberg

Daniel Skinner

Charles Anthony Smith

Elizabeth S. Smith

Eric R.A.N. Smith

Miriam Smith

Wendy G. Smooth

Rorie L. Spill Solberg

Donald R. Songer

Cheryl Logan Sparks-Walniuk

Valerie Sperling

Niels Spierings

Mary A. Stegmaier

Linda S. Stevenson

Judith H. Stiehm

Heather Stoll

Patricia Strach

Dara Z. Strolovitch 
Donley T. Studlar

Tracy Sulkin

Michele L. Swers

Liam Swiss

Katherine Tate

Michelle M. Taylor-Robinson

Mary Ann Reed Tetreault

Gunes Murat Tezcur

Sean M. Theriault

Melanee Thomas

Sue Thomas

Aili Mari Tripp

John Tuman

Melody Ellis Valdini

Celia Valiente

Jill Mccalla Vickers

Jennifer Nicoll Victor

Jocelyn Viterna
Lena Wängnerud

Bram Wauters

Herbert F. Weisberg

Bozena Welborne

Jason Harold Windett

Susanna D. Wing

Nicholas Winter

Christina Wolbrecht

Patricia J. Woods

Oliver H. Woshinsky

Matt Wright

Priscilla Yamin

Alixandra Yanus

Mi Yung Yoon

Antoine Yoshinaka

Elizabeth Zechmeister

Cyrus Ernesto Zirakzadeh

Susanne Zwingel 


\section{Index to Volume 9}

Alexander-Floyd, Nikol G. (Inter)disciplinary Trouble:

Intersectionality, Narrative Analysis, and the Making of a New Political Science

Atchison, Amy L. Introduction: Teaching Gender and Politics:

Views from the Field

Atchison, Amy L. The Practical Process of Gender Mainstreaming in the Political Science Curriculum

Bedford, Kate. Reflections from a Visitor

Beltrán, Cristina. Crossings and Correspondences: Rethinking Intersectionality and the Category "Latino"

Browne, Jude. The Default Model: Gender Equality, Fatherhood, and Structural Constraint

Caglar, Gülay. Gender Mainstreaming

Carroll, Susan J. Introduction: Crossing Borders, Transforming Knowledge: Celebrating 25 Years of the Women and Politics Program at Rutgers University

Cassese, Erin C. and Angela L. Bos. A Hidden Curriculum? Examining the Gender Content in Introductory Level Political Science Textbooks

Childs, Sarah. Negotiating Gendered Institutions: Women's Parliamentary Friendships

Clark, Jennifer Hayes and Veronica Caro. Multimember Districts and the Substantive Representation of Women: An Analysis of Legislative Cosponsorship Networks

Corrigan, Rose. Building Theory and Making Change: The Challenges of Studying Feminist Activism 
Crage, Suzanna M., Melanie M. Hughes, Pete Mohanty, and

Terri E. Givens. Gendered Jobs: Integrating Immigrants versus

Controlling Immigration in the European Union

Crane-Seeber, Jesse and Betsy Crane. What Does Evolution Have To Do with Legal Enclaves?

Crowder-Meyer, Melody. Gendered Recruitment without Trying: How Local Party Recruiters Affect Women’s Representation

DeLaet, Debra L. The Limitations of Law as a Tool for

Responding to Violence Against Women

Doherty, Leanne. Gender Mainstreaming in Political Science Experiential Learning Programs

Eichler, Maya. Militarizing Men: Gender, Conscription, and War in Post-Soviet Russia. Reviewed by Laura Sjoberg

Esarey, Justin and Gina Chirillo. "Fairer Sex" or Purity Myth?

Corruption, Gender, and Institutional Context

Franceschet, Susan and Jennifer M. Piscopo. Equality,

Democracy, and the Broadening and Deepening of Gender Quotas

Harell, Allison and Dimitrios Panagos. Locating the Aboriginal Gender Gap: The Political Attitudes and Participation of Aboriginal Women in Canada

Johnson, Janet Elise, Porgerður Einarsdóttir, and Gyða Margrét

Pétursdóttir. A Feminist Theory of Corruption: Lessons from Iceland

Kenney, Sally J. Gender and Justice: Why Women in the Judiciary Really Matter. Reviewed by Susan J. Carroll

Krook, Mona Lena and Andrea Messing-Mathie. Gender Quotas and Comparative Politics: Past, Present, and Future Research Agendas

Lépinard, Éléonore. For Women Only? Gender Quotas and Intersectionality in France 
Liebowitz, Debra J. Comprehension Obscured: Feminist Ideas and Policy Directives

Lyle-Gonga, Marsha. A Critical Analysis of Gender Mainstreaming

Matthes, Melissa. Conclusion and Rejoinders: Teaching Gender Politics: Views from the Field

McDermott, Rose. A Feminist Scientific Approach to the Analysis of Politics and Gender

Murray, Rainbow. Quotas, Citizens, and Norms of Representation

Nayak, Meghana. The False Choice between Universalism and Religion/Culture

Osborn, Tracy L. How Women Represent Women: Political Parties, Gender, and Representation in the State Legislatures Reviewed by Sue Thomas

Pearson, Kathryn and Eric McGhee. What It Takes to Win: Questioning "Gender Neutral" Outcomes in U.S. House Elections

Penttinen, Elina. Posthumanism and Feminist International Relations

Prügl, Elisabeth. Introduction: International Feminist Strategies

Schreiber, Ronnee. How Studying Ideological Diversity among Women Transforms Political Knowledge

Snyder-Hall, Claire. Reflections of a Politically Engaged Scholar 466

Solanki, Gopika. The Retelling of Tales: Disentangling the Feminist Evolutionary Analytic Approach, Legal Pluralism, and Gender Justice

True, Jacqui. Counting Women and Balancing Gender: Increasing Women's Participation in Governance

True, Jacqui. Introduction: Violence Against Women, Family Law, and the Feminist Evolutionary Analytic Approach 
Valdini, Melody Ellis. Electoral Institutions and the Manifestation of Bias: The Effect of the Personal Vote on the Representation of Women

Vanlangenakker, Ine, Bram Wauters, and Bart Maddens. Pushed Toward the Exit? How Female MPs Leave Parliament

Walsh, Denise. A Feminist Approach to Quotas and Comparative Politics

Wittmer, Dana E. and Vanessa Bouché. The Limits of Gendered Leadership: Policy Implications of Female Leadership on "Women's Issues"

Yamin, Priscilla. American Marriage. A Political Institution Reviewed by Jyl Josephson

Zetterberg, Pär. The Dynamic Relationship between Gender Quotas and Political Institutions

Zwingel, Susanne. International Feminist Strategies: Strengths and Challenges of the Rights-Based Approach 


\section{CAMBRIDGE}

\section{Outstanding Titles from Cambridge}

E-books Available for most titles!
Antigone, Interrupted

Bonnie Honig

585.00: Hb: 978-1-107-03697-0: 338 pp. S29.99: Pb: 978-1-107-66815-7

Dialogue, Politics and Gender

Edited by Jude Browne

S95.00: Hb: 978-1-107-03889-9: $276 \mathrm{pp}$. \$32.99: Pb: 978-1-107-65356-6

\section{Dressing Constitutionally}

Hierarchy, Sexuality, and Democracy from Our Hairstyles to Our Shoes

\section{Ruthann Robson}

S90.00: $\mathrm{Hb}: 978-0-521-76165-9: 264 \mathrm{pp}$. S32.99: Pb: 978-0-521-14004-1

Conscription, Family, and the Modern State A Comparative Study of France and the United States

Dorit Geva

\$90.00: Hb: 978-1-107-02498-4: 280 pp.

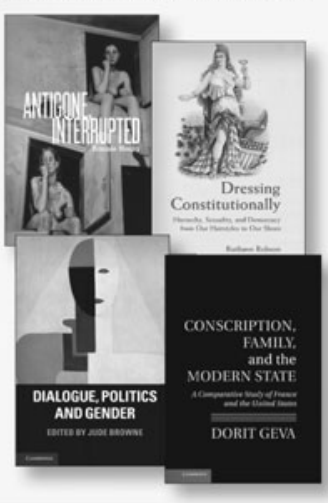

Cambridge Studies in Contentious Politics

The Language of Contention Revolutions in Words, 1688-2012

Sidney Tarrow

\$80.00: Hb: 978-1-107-03624-6 S27.99: Pb: 978-1-107-69328-9: $272 \mathrm{pp}$.

Informal Labor, Formal Politics, and Dignified Discontent in India

\section{Rina Agarwala}

S90.00: Hb: 978-1-107-02572-1 S29.99: Pb: 978-1-107-66308-4: $266 \mathrm{pp}$.

Sterilized by the State Eugenics, Race, and the Population Scare in TwentiethCentury North America

Randall Hansen and Desmond King

s85.00: Hb: 978-1-107-03292-7: 328 pp. S29.99: Pb: 978-1-107-65970-4

Slavery, Abortion, and the Politics of Constitutional Meaning Justin Buckley Dyer S90.00: Hb: 978-1-107-03194-4: 202 pp. S29.99: Pb: 978-1-107-68074-6
A Most Masculine State Gender, Politics and Religion in Saudi Arabia

Madawi Al-Rasheed Cambridge Middle East Studies 590.00: $\mathrm{Hb}$ : 978-0-521-76104-8: $334 \mathrm{pp}$. \$29.99: Pb: $978-0-521-12252-8$

\section{Making Citizens in Africa}

Ethnicity, Gender, and

National Identity in Ethiopia

Lahra Smith

African Studies

\$85.00: Hb: 978-1-107-03531-7: 276 pp. S29.99: Pb: 978-1-107-61038-5

\section{Democratic Theory and} Causal Methodology in Comparative Politics

Mark I. Lichbach

585.00: Hb: 978-1-107-02581-3: 264 pp. S32.99: Pb: 978-1-107-62235-7

\section{Textbook}

The American Congress Eight Edition

Steven S. Smith, Jason M. Roberts, and yan J. Vander Wielen \$65.00: Pb: 978-1-107-61824-4: 416 pp.

\section{Textbook}

The Fundamentals of Political Science Research Second Edition

Paul Kellstedt and Guy Whitten

\$75.00: Pb: 978-1-107-62166-4: $336 \mathrm{pp}$. Prices subject to change. 


\section{Politics E Gender}

\section{INSTRUCTIONS TO CONTRIBUTORS}

\begin{abstract}
Politics \& Gender accepts manuscript submissions through the Editorial Manager system at http://www.editorialmanager.com/pag

For questions concerning "Instructions to Contributors," please contact the Editor, Jennifer Lawless at lawless@american.edu. Additional information can be found at the journal's website at http://www.journals.cambridge.org/ action/displayJournal?jid=PAG
\end{abstract}

\section{BOOK REVIEWS}

Suggestions of books to be reviewed should be emailed to the Book Review Editor:

Sue Tolleson-Rinehart

University of North Carolina

suetr@unc.edu

\section{MANUSCRIPT PREPARATION}

- Manuscripts must be no longer than 30 pages including text, tables and figures, references and appendices. The entire manuscript (including notes and references) must be double-spaced, with one-inch margins and 12-point font, and printed on one side of the page only.

- The author must include a separate title page, with his or her full contact information (including email address, telephone number and institutional affiliation), and a brief biographical statement. All identifying information must be removed from the manuscript.

- A second page must include an abstract of no more than 200 words.

- Placement of tables or figures should be cited in the text. The publisher will be responsible for placing artwork, tables or figures, as well as converting endnotes to footnotes.

- Appendices, tables, and figures should be numbered consecutively throughout the article and be included on separate pages appearing after the reference section. Figures should be ready for photographic reproduction; they cannot be redrawn by the publisher. Charts, graphs, or other artwork should be professional rendered or computer generated as TIFF or EPS files. Photographs should be clearly printed and should remain legible after a $50 \%$ reduction.

- References and notes should conform to the APSA Style Manual. Authors should include full volume, issue, and page numbers for references. Author's acknowledgments or other personal notes will appear as an unnumbered note at the foot of the first page. Notes should be numbered consecutively throughout the article. Numbered notes should appear at the end of the sentence. If multiple texts are cited in a sentence, they should appear as one consolidated note at the end of the sentence.

- Endnotes should be employed (rather than footnotes).

- All figure captions should be typed on a separate page (or pages), rather than on the figures themselves (which are camera-ready TIFF or EPS files) so that they can be copyedited.

Originality and copyright: Papers with multiple authors are reviewed with the assumption that all authors concur with its submission. A Copyright Transfer Agreement, with certain specified rights reserved by the author, must be signed and returned to the Editor by senior authors of accepted manuscripts, prior to publication. Politics \& Gender does not accept manuscripts for review that are under review elsewhere, previously published or already committed for publication.

For general guidelines for preparing a manuscript for submission, please refer to the APSA Style Manual for Political Science (rev. ed. 2001) for citation, footnotes, references, and other style issues. Please note, in particular, the statement on gender-specific language (15). 


\section{Politics E Gender}

Volume 9 | Number 4 | December 2013

\section{ARTICLES}

"Fairer Sex" or Purity Myth? Corruption, Gender, and Institutional Context Justin Esarey and Gina Chirillo

Gendered Recruitment without Trying: How Local Party Recruiters

Affect Women's Representation

Melody Crowder-Meyer

Locating the Aboriginal Gender Gap: The Political Attitudes and

Participation of Aboriginal Women in Canada

Allison Harell and Dimitrios Panagos

What It Takes to Win: Questioning "Gender Neutral" Outcomes

in U.S. House Elections

Kathryn Pearson and Eric McGhee

\section{CRITICAL PERSPECTIVES ON GENDER AND POLITICS}

Crossing Borders, Transforming Knowledge: Celebrating 25 Years of the Women and Politics Program at Rutgers University

Introduction

Susan J. Carroll

Reflections of a Politically Engaged Scholar

Claire Snyder-Hall

(Inter)disciplinary Trouble: Intersectionality, Narrative Analysis,

and the Making of a New Political Science

Nikol G. Alexander-Floyd

How Studying Ideological Diversity among Women Transforms

Political Knowledge

Ronnee Schreiber

Crossings and Correspondences: Rethinking Intersectionality

and the Category "Latino"

Cristina Beltrán

Reflections from a Visitor

Kate Bedford

Building Theory and Making Change: The Challenges of Studying

Feminist Activism

Rose Corrigan

Comprehension Obscured: Feminist Ideas and Policy Directives

Debra J. Liebowitz

BOOK REVIEWS $\quad 498$

$\begin{array}{ll}\text { ERRATUM } & 504\end{array}$

REVIEWER LIST $\quad 505$

\begin{tabular}{lr} 
INDEX TO VOLUME 9 & 510 \\
\hline
\end{tabular} 